\title{
Fungsi Rekruitmen Politik Calon Legislatif Partai GERINDRA pada Pemilihan Umum 2019 di Daerah Khusus Ibukota Jakarta
}

\author{
The Function of Political Recruitment for Legislative \\ Candidates of the GERINDRA Party in the 2019 General \\ Election in the Daerah Khusus Ibukota Jakarta \\ Aisatul Husna*, Ari Ganjar Herdiansah \& Firman Manan \\ Ilmu Politik, Fakultas Ilmu Sosial dan Ilmu Politik, Universitas Padjadjaran, Indonesia
}

Diterima: April 2019; Disetujui: Mei 2019; Dipublish: Juni 2019.

\begin{abstract}
Abstrak
Penelitian ini bertujuan untuk mengetahui perubahan pola rekruitmen calon anggota legislatif Partai Gerindra pasca ditetapkan sebagai partai terbuka pada pemilu 2019 di DKI Jakarta dan mengetahui fungsi dari rekruitmen kader untuk di persiapkan di calon anggota legislatif partai Gerindra 2019 di DKI Jakarta. Rekruitmen yang dianut oleh Partai Gerindra adalah semi terbuka karena semua masyarakat yang memenuhi syarat dapat dipilih sebagai calon legislatif dari partai. Penelitian ini menggunakan metode kualitatif, dengan jenis penelitian deskriptif. Pengumpulan data melalui observasi dan wawancara. Indonesia sudah multipartai, yang terdaftar di pemilihan umum 20 partai politik. Partai politik di Indonesia adalah institusi yang dianggap penting di dalam sistem demokrasi. Oleh karena itu, partai politik berkewajiban untuk melakukan rekrutmen untuk calon anggota legislatif yang nantinya kader-kader partai akan ditempatkan di parlemen dan juga melalui seleksi terbuka baik kader internal maupun eksternal. Partai Gerindra dalam menghadapi pemilu 2019 memiliki kebijakan untuk menerapkan mekanisme rekrutmen calon anggota legislatif. Dengan demikian diharapkan mampu memunculkan wakil-wakil rakyat yang terbaik di pemilu tahun 2019, baik pada tingkat DPR RI, DPRD Provinsi, dan DPRD Kota/Kabupaten.
\end{abstract}

Keywords: Rekruitmen Politik, Pemilihan Umum Legislatif, Partai Gerindra.

\begin{abstract}
This study aims to determine the changes in the pattern of recruitment of Gerindra Party legislative candidates after being declared an open party in the 2019 election in DKI Jakarta and to know the function of cadre recruitment to be prepared in the Gerindra 2019 party legislative candidates in DKI Jakarta. The recruitment by the Gerindra Party is semi-open because all people who fulfill the requirements can be chosen as legislative candidates from the party. This research uses qualitative methods, with descriptive research types. Data collection through observation and interviews. 2019 elections have 20 political parties. Political parties in Indonesia are institutions that are considered important in a democratic system. Therefore, political parties are obliged to recruit candidates for legislative members who later party cadres will be placed in parliament and also through open selection both internal and external cadres. The Gerindra Party in facing the 2019 election has a policy to implement a recruitment mechanism for legislative candidates. Thus it is hoped that the best representatives of the people will be able to emerge in the 2019 elections, both at the level of the DPR RI, Provincial DPRD and City / Regency DPRD.
\end{abstract}

Keywords: Political Recruitment, Legislative General Election, Gerindra Party.

How to Cite: Husna, A. Manan, F. \& Herdiansah, A.G. (2019): Fungsi Rekruitmen Politik Calon Legislatif Partai GERINDRA pada Pemilihan Umum 2019 Di Daerah Khusus Ibukota Jakarta, JUPIIS: Jurnal Pendidikan Ilmu-ilmu Sosial, 11 (1): 65-73 


\section{PENDAHULUAN}

Rekrutmen politik memiliki fungsi memelihara sistem sekaligus sebagai saluran perubahan. Studi mengenai rekrutmen politik biasanya difokuskan pada aturan main yang dijalankan di dalam partai politik itu sendiri. Kepentingan partai politik dalam proses rekrutmen bervariasi di setiap negara. Rekrutmen anggota legislatif oleh partai politik secara umum mencakup tiga tahap penting yang pertama penjaringan calon, dimana dalam tahapan ini mencakup interaksi antara elite partai di tingkat lokal atau ranting partai dengan elite partai di tingkat atasnya atau anak cabang, kedua penyaringan dan seleksi calon yang telah ditetapkan.

Tahapan ini melibatkan interaksi antara elit tingkat cabang daerah, terutama pengurus harian partai tingkat cabang dengan tim kecil yang dibentuk dan diberikan wewenang menetapkan calon legislatif. Akibatnya, derajat demokratisasi partai politik turut menentukan kualitas anggota legislatif.

Proses rekrutmen dalam partai politik menunjukkan adanya tiga komponen awal yang harus diperhatikan, antara lain sistem hukum atau legal system. Hal ini menyangkut aturan-aturan formal dan aturan-aturan yang dibuat dalam proses awal dari seleksi, sistem pemilihan umum, apakah menggunakan sistem distrik atau sistem proporsional, dan proses rekrutmen itu sendiri. Dalam proses ini akan bertemu tuntutan penjaga gawang (gatekeepers) atau yang melakukan seleksi dengan tuntutan kandidat.

Proses ini akan menghasilkan output di dalam proses rekrutmen. Sedangkan dalam prosedur nominasi berbeda-beda antara satu negara dengan negara lain dan dapat dibedakan dengan sejumlah faktor, yang meliputi luasnya partisipasi dan sentralisasi atau desentralisasi dari proses rekrutmen itu. Berorientasi patronage dengan sistem yang birokratis.
Partai politik merupakan salah satu institusi inti dari pelaksanaan demokrasi (Pasaribu, 2017). Demokrasi dengan sebuah sistem yang disebut keterwakilan (representativeness), baik keterwakilan dalam lembaga formal kenegaraan seperti lembaga legislatif (DPR/DPRD) maupun keterwakilan aspirasi masyarakat dalam institusi kepartaian. Berbeda dengan demokrasi langsung di masa Yunani Kuno, demokrasi dengan sebagai demokrasi tidak langsung membutuhkan media penyampain pesan politik kepada negara (pemerintah) yang biasa disebut partai politik dan keberadaannya diatur dalam konstitusi negara (Koirudin, 2004).

Citra partai politik tidak adapat dibangun dengan waktu singkat, namun membutuhkan proses yang panjang. Citra hanya dapat dibangun melalui aktivitas tokoh dan partai politik di masyarakat. Ketika tokoh partai politik duduk dalam pemerintahan dapat menunjukkan prestasi, maka denagn itu akan mendapat penilaian yang positif (Nurdiansyah, 2018).

Dalam kepustakaan ilmu politik dan sosiologi politik, pemilu dianggap sebagai saat terpenting untuk rekrutmen politik. Hal ini dikarenakan dalam pemilu rakyat atau para konstituen memilih caloncalonnya melalui partai-partai politik yang menjadi kontestan pemilu (Kleden, 2005).

Rekrutmen merupakan tempat untuk membangun kaderisasi, regenerasi, dan seleksi para kandidat serta membangun legitimasi dan relasi antara partai dengan masyarakat sipil (Eko, 2003).

Fungsi rekrutmen politik adalah suatu proses seleksi atau rekrutmen anggota-anggota kelompok untuk mewakili kelompoknya dalam jabatanjabatan administratif maupun politik. Setiap sistem politik memiliki sistem atau prosedur-prosedur rekrutmen yang berbeda. Partai politik yang ada seharusnya dapat melakukan mekanisme rekrutmen politik yang dapat menghasilkan pelaku-pelaku politik yang 
berkualitas di masyarakat (Kadir, 2013). Salah satu tugas pokok dalam rekrutmen politik adalah bagaimana partai-partai politik yang ada dapat menyediakan kader-kadernya yang berkualitas untuk duduk di lembaga legislatif (DPR/DPRD).

Era reformasi telah menghasilkan sejumlah perubahan signifikan dalam masyarakat politik. Pertama, perubahan dari bureaucratic government ke party government. Kedua, hadirnya multipartai yang jauh lebih terbuka dan kompetitif. Ketiga, proses rekrutmen parlemen berlangsung lebih terbuka dan kompetitif, dengan campur tangan yang minimal dari tangan-tangan penguasa dan birokrasi. Keempat, parlemen baik pusat maupun daerah jauh lebih powerful ketimbang parlemen di masa lalu. Namun, perubahan itu bersifat transisional dan belum sempurna sehingga tidak mempunyai kontribusi yang pasti terhadap konsolidasi demokrasi, khususnya di sektor masyarakat politik.

Salah satu fungsi partai politik adalah melakukan rekrutmen politik, yaitu merekrut orang-orang untuk menjadi anggota partai dan aktif dalam aktivitas partai, serta menyeleksi anggota-anggota partai yang berbakat untuk dipersiapkan menjadi calon-calon pemimpin (Haryanto, 1982). Pada umumnya cara yang ditempuh oleh partai politik adalah dengan menarik golongan muda untuk dididik dijadikan kader. Dari para kader ini akan tampak anggota-anggota yang mempunyai bakat yang pada gilirannya dapat untuk dijadikan calon-calon pemimpin. Pemimpin dalam konteks ini adalah menjadi anggota lembaga perwakilan rakyat serta pejabat publik yakni kepala negara dan pemerintahan juga kepala daerah yang dipilih oleh rakyat (Budiardjo, 2004).

Partai Gerindra sebagai partai yang mendeklarasikan dirinya sebagai partai kader, memiliki sistem kaderisasi kepartaian yang sistematis dan metodik. Kaderisasi ini memiliki fungsi rekrutmen calon anggota dan fungsi pembinaan untuk seluruh anggota, kader dan fungsionaris partai. Fungsi-fungsi ini dijalankan secara terbuka melalui infrastruktur kelembagaan yang tersebar dari tingkat pusat sampai tingkat ranting. Fungsionalisasi berjalan sepanjang waktu selaras dengan tujuan dan sasaran umum partai, khususnya dalam bidang penyiapan sumber daya manusia partai. Meskipun Partai Gerindra dilihat sebagai partai yang sedikit banyak telah mencoba konsisten dengan asas dan tujuan yang ingin diciptakan dalam program politiknya secara inklusif yakni partai kader, namun perlu dianalisis lebih lanjut tentang proses rekrutmen calon legislatifnya.

Dalam pemilu Partai Gerindra meraih di tahun 2009 ada 6 kursi, di tahun 2014 ada 15 kursi di DPRD DKI Jakarta, sedangkan target di tahun 2019 ini ada 30 kursi DPRD DKI Jakarta dari fraksi partai Gerindra tergolong lebih eksis, di tahun 2019 terpilih DPRD DKI Jakarta untuk partai Gerindra 19 kursi. Simbolisasi sebagai partai yang bersih dan bisa dipercaya yang dibawa Partai Gerindra mampu memobilisasi massa dengan cepat di DKI Jakarta untuk isu-isu nasional disaat yang sama, kaderisasi Partai Gerindra dimulai di kampus-kampus penting di khususnya di DKI Jakarta yang berbasis gerakan dengan organisasi sayap.

Partai Gerindra mempunyai karakteristik sebagai partai politik massa yang begitu agresif. Secara ideologis, Partai Gerindra diuntungkan oleh pilihannya menjadikan sebagai asas dan meskipun eksklusif, dia bisa memainkan pencitraan sebagai partai politik bersih. Fenomena politik yang diwakili oleh Partai Gerindra yang percaya pada jalur demokrasi untuk mendapatkan kekuasaan atau minimal berpartisipasi di dalamnya menarik untuk dikaji lebih jauh. Terkait dengan cara membangun basis konstituen dan menempatkan diri sebagai partai massa, Partai Gerindra membutuhkan strategi baru yang memungkinkannya 
memunculkan organ-organ strategis disamping mendapatkan konstituen dari basis organisasi yang sudah bagus. Partai Gerindra memilih konsisten pada bentuk negara yang diamanatkan oleh konstitusi. Bahkan penegasan basis ideologis dan jaringan sosial Partai Gerindra sudah tampak kepermukaan bisa berlaku efektif dan berpotensi besar menjadi partai politik gerakan yang dominan dalam kompetisi politik nasional.

Masing-masing partai politik harus berusaha menjadi dominan dalam masyarakat. Posisi yang kuat dalam masyarakat membuat suatu partai politik selalu diingat dan menjadi referensi bagi masyarakat ketika mereka dihadapkan pada serangkaian pilihan politik (Rifai, 2016).

Setelah lima kali melakukan pemilu sejak Era Reformasi, yakni Pemilu 1999, 2004, 2009, 2014 dan 2019 serta terjadinya untuk kaderisasi partai politik dalam kontestasi anggota legislatif dengan memperoleh kekuasaan.

\section{METODE PENELITIAN}

Penelitian ini menggunakan metode kualitatif, dengan jenis penelitian deskriptif. Pengumpulan data melalui observasi dan wawancara. Analisis data menggunakan analisis data kualitatif atau interpretatif. Analisis data kualitatif yang dipergunakan untuk menganalisis data yang sifatnya monografi atau wujud kasuskasus sehingga tidak dapat disusun ke dalam suatu struktur klarifikasi (Koentjoroningrat, 1998).

Pengumpulan data melalui wawancara, observasi dan dokumentasi. Informan dalam penelitian ini adalah pengurus dari DPD Partai Gerindra DKI Jakarta dan calon legislatif internal dan eksternal. Analisis data menggunakan analisis data kualitatif atau interpretatif. Analisis data kualitatif yang dipergunakan untuk menganalisis data yang sifatnya monografi atau wujud kasus-kasus sehingga tidak dapat disusun ke dalam suatu struktur klarifikasi. Pendekatan interpretatif dilakukan melalui tahapan reduksi data pengorganisasian data, dan kemudian menginterprestasikannya. Dengan demikian, data yang di peroleh dari penelitian ini diorganisasikan, dikategorikan, dan kemudian diinterprestasikan secara rasional agar mendapatkan suatu kesimpulan yang terjamin validitasnya

Data penelitian ini juga didukung dari sumber-sumber sekunder seperti buku, jurnal, dan pemberitaan media massa yang relevan dengan kajian penelitian. Penelitian ini dalam kebijakan pendekatan interpretatif dilakukan melalui tahapan reduksi data pengorganisasian data, dan kemudian menginterprestasikannya. Dengan demikian, data yang di peroleh dari penelitian ini diorganisasikan, dikategorikan, dan kemudian diinterprestasikan secara rasional agar mendapatkan suatu kesimpulan yang terjamin validitasnya.

\section{HASIL DAN PEMBAHASAN}

\section{Pola Rekruitmen Calon Anggota Legislatif Partai Gerindra}

Partai Gerindra telah sah menjadi salah satu partai peserta Pemilu 2019 dengan nomor urut dua. Partai politik yang telah lulus verifikasi dengan syarat sebagaimana dimaksud tidak diverifikasi ulang dan ditetapkan sebagai Partai Politik Peserta Pemilu, bunyi Pasal 173 ayat (3) UU No. 7 Tahun 2017 ini. DPD Partai Gerindra DKI Jakarta dalam pencalonan ini mengajukan 106 orang bakal calon anggota legislatif agar dapat mewakili partainya di kursi pemerintahan. Dari orang 106 bakal calon anggota legislatif Partai Gerindra tersebut tersebar di DKI Jakarta. Dengan target untuk DPRD DKI Jakarta Gerindra dengan 30 kursi.

Rekrutmen politik adalah suatu proses seleksi anggota-anggota kelompok untuk mewakili kelompoknya dalam jabatan administratif maupun politik (Putra, 2003). 
Dalam pengertian lain rekrutmen politik merupakan fungsi penyeleksian rakyat untuk kegiatan politik dan jabatan pemerintahan melalui penampilan dalam media komunikasi, menjadi anggota organisasi, mencalonkan diri untuk jabatan tertentu dan sebagainya (Sastroatmodjo, 1995).

Mekanisme rekruitmen anggota calon legisltaif Partai Gerindra atau yang disebut dengan tahapan panitia penjaringan khusus tingkat daerah merupakan tahap panjang yang harus dilakukan setiap menjelang pemilu. Prosesnya terdiri dari: 1) Pembentukan panitia penjaringan khusus, 2) Sosialisasi ke seluruh kader, 3) Penjaringan oleh kader, 4) Verifikasi Bakal Calon Anggota Legislatif; 5) Rapat Pleno pemilihan umum internal, 6) Penetapan nomor urut calon legisltaif, 7) pengesahan dan pengajuan Bakal Calon Anggota Legislatif ke Dewan Pengurus Wilayah dan 8) Penetapan Calon legisltaif oleh Komisi Pemilihan Umum. Proses rekruitmen calon legisltaif Partai Gerindra yang telah diuraikan yang melalui proses rapat pleno pemilihan Umum Internal dan eksternal melalui pendaftaran terbuka. Kegiatan pemilihan umum internal dan eksternal terdiri atas: 1) Sosialisasi pemilihan umum internal; 2) Penetapan Daftar Pemilih Tetap pemilihan umum internal; 3) Inventarisasi dan verifikasi Daftar Bakal Calon, 4) Penetapan Daftar Calon Sementara; 5) Penetapan Daftar Calon Tetap, 6) Sosialisasi Daftar Calon Tetap, 7) Pemungutan dan Penghitungan Suara; dan 8) Penetapan Anggota.

Tim rekruitmen calon legislatif partai politik menyeleksi kelengkapan administrasi berkas lamaran bakal calon anggota legislatif sebagaimana bebeberapa kriteria kelengkapan administrasiyang diwajibkan untuk dilengkapi oleh bakal calon anggota legislatif (U.B \& Sukmana, 2015).

Pelaksanaan pemilihan umum internal dan eksternal untuk memilih anggota dewan Calon legisltaif. Pada pemilihan Calon legisltaif dari DPD kemudian diajukan ke Dewan Pengurus Wilayah untuk disetujui kemudian baru di ajukan ke Komisi Pemilihan Umum sedangkan dalam Panduan pemilihan umum internal yang khusus mengatur tentang pemilihan Dewan Pimpinan Tingkat Wilayah dan Dewan Pimpinan Tingkat Daerah maka setelah hasil perhitungan dari pemungutan suara kemudian diajukan ke Dewan Pengurus Wilayah untuk ditetapkan dengan SK Penetapan dan proses secara otomatis selesai.

Setiap partai politik yang melakukan sebuah proses rekruitmen tentunya memiliki hambatan yang berbeda-beda. Masalah anggaran untuk melakukan kegiatan pelatihan kaderisasi. Jumlah kader terus bertambah namun dana dalam proses kaderisasi terbatas menjadikan salh satu hambatan kendala bagi rekrutmen kader (Fajrina, 2017).

Mekanisme rekruitmen Partai Gerindra dalam pelaksanaannya sudah sesuai dengan ADART Partai Gerindra Bab V Anggota dan Kader, Pasal 14 ayat 4 bahwa kader partai Gerindra dipersiapkan untuk menjadi a) Calon Pengurus Partai, b) Bakal calon Anggota DPR dan DPRD, c) Bakal calon Kepala Daerah dan Wakil Kepala Daerah, dan d) Bakal calon Presiden dan Wakil Presiden . Oleh karena itu, berdasarkan ADART tersebut dapat dilihat dengan jelas bahwa Partai Gerindra lebih mengutamakan anggota partai/kader sebagai calon anggota DPR atau DPRD.

Dalam rekruitmen politik seperti yang telah diungkapkan dalam kerangka teori ada tipe-tipe rekruitmen yang dapat diikuti oleh partai politik. (Putra, 2003) yaitu yang pertama partisan, yaitu merupakan pendukung yang kuat, loyalitas tinggi terhadap partai sehingga bisa direkrut untuk menduduki jabatan strategis. Kedua Compartmentalization, merupakan proses rekrutmen yang didasarkan pada latar belakang pendidikan dan pengalaman organisasi 
atau kegiatan sosial politik seseorang, misalnya aktivis LSM. Tipe ini menjadi point pertimbangan dalam proses penentuan calon Anggota legislatif. Dalam partai Gerindra tipe ini dijadikan pertimbangan utama untuk memilih calon legislatif dari eksternal. Seluruh calon anggota legislatif yang akan duduk di kursi Parlemen harus memiliki pendidikan serendah-rendahnya Sekolah Menengah Atas (SMA) atau sederajat, karena ketentuan tersebut sudah diatur di dalam peraturan Undang-Undang Nomor 8 tahun 2012 tentang Pemilihan Umum Anggota Dewan Perwakilan Rakyat, Dewan Perwakilan Daerah, dan Dewan Perwakilan Rakyat Daerah. Ketiga Immediate Survival, yaitu proses rekrutmen yang dilakukan oleh otoritas pemimpin partai tanpa memperhatikan kemampuan orang-orang yang akan direkrut. Tipe Immediate Survival tidak digunakan dalam proses rekruitmen di Partai Gerindra karena memang tidak sesuai dengan kenyataan. Mekanisme rekruitmen di Partai Gerindra yaitu pimpinan Dewan Pengurus Daerah/Dewan Penguruh Wilayah tidak punya otoritas untuk menetapkan calon legislatif karena penetapan calon berdasarkan rapat pleno pemilihan umum internal berdasaarkan kemampuan, loyalitas, pengalaman dan ketokohan seorang calon. Keempat Civil Service Reform, merupakan proses rekrutmen berdasarkan kemampuan dan loyalitas seorang calon sehingga bisa mendapatkan kedudukan lebih penting atau tinggi. Tipe ini dalam Partai Gerindra hampir sama dengan tipe partisipan, tipe ini menjadi kriteria dasar dalam perekrutan kader atau eksternal karena dinilai dari berbagai segi yaitu kriteriakritreia tertentu, distribusi-distribusi kekuasaan, bakat-bakat yang terdapat di dalam masyarakat, langsung tidak langsung menguntungkan partai politik.

Partai Gerindra dalam pelaksanaan rekruitmen anggota calon legislatif untuk pemilu 2019 menggunakan sistem semi terbuka. Dalam sistem ini tidak sepenuhnya dengan pola terbuka. Seperti menurut Haryanto bahwa rekrutmen politik terbuka mengandung makna bahwa semua warga negara yang memenuhi syarat-syarat yang ditentukan serta mempunyai bakat, tanpa kecuali mempunyai kesempatan yang sama untuk menduduki jabatan politik maupun jabatan pemerintahan. Sebaliknya, rekrutmen politik tertutup hanya memberikan kesempatan kepada orangorang tertentu seperti kawan-kawan akrab penguasa, atau individu-inidividu yang mempunyai persamaan agama, daerah, etnis bahkan keluarga dari pihak penguasa (Syamsir \& Suryaney, 2005).

Pencitraan politik pada dasarnya memiliki tujuan untuk memperoleh vote setelah proses kampanye. Pada dasarnya keputusan masyarakat untuk memberikan hak pilihnya pada sebuah partai atau calon legislatif dengan visi dan misi kandidat. Politisi harus mampu membangun political branding yang kuat agar bisa memperoleh kepercayaan dan loyalitas dari masyarakat selaku pemilih (Al-Husainni \& Fuady, 2016).

Setiap warga negara dapat menjadi Calon legisltaif (calon legislatif) atau Pengurus Partai Gerindra dengan memenuhi persyaratan dan prosedur yang telah ditetapkan oleh ketentuan dan aturan resmi Partai Gerindra. Partai Gerindra sebagai partai gerakan, sangat menghormati keberagaman, berbagai macam ras, suku dan agama, mengajak seluruh pihak dan komponen bangsauntuk bersama-sama bersinergi untuk pembangunan Bangsa ini ${ }^{1}$.

1 Wawancara dengan Sekretaris DPD Partai Gerindra DKI Jakarta, Husni Thamrin, tanggal 07 Maret 2019, pukul 14.00 sd Selesai, bertempat di Sarinah. 
Rekrutmen dengan pola semi terbuka yang diterapkan oleh Partai Gerindra berarti menerapkan merit system, yaitu suatu seleksi menurut kualifikasi teknis, rasional dan impersonal. Sedangkan dalam hal rekrutmen calon legisltaif, harus mencerminkan perwakilan yang sebenarnya dari masyarakat. Seleksi anggota legislatif harus memenuhi syaratsyarat kapabilitas, popularitas dan akseptabilitas. Ketiga syarat ini harus dipadukan. Artinya sesorang kandidat harus benar-benar memiliki kemampuan, populer di tengah-tengah masyarakat, diterima oleh masyarakat serta terpilih melalui prosedur perwakilan, bukan hanya ditunjuk.

Dalam sistem semi terbuka ini setiap warga negara tidak memiliki kebebasan yang mutlak dalam berkompetisi menjadi calon legislatif di Partai Gerindra. Dalam melakukan penyeleksian, Sebelum seorang calon anggota legislatif diajukan kepada Komisi Pemilihan Umum, Partai Gerindra terlebih dahulu melakukan rekruitmen atau penyeleksian terhadap calon legislatif, baik penelitian terhadap persyaratan administrasi yang mencakup legalitas dari penilaian ijazah, kesehatan, maupun keterangan bebas hukum. Tak hanya itu Partai Gerindra juga melakukan penilaian terhadap moralitas calon anggota legislatif misalnya ketaatan ibadah, kemampuan baca kitab suci serta kecakapan berkomunikasi berdasarkan etika berbahasa.

Pola rekrutmen politik memiliki keragaman walaupun ada dua cara seleksi pemilihan melalui ujian dan latihan yang dianggap paling penting. Namun disamping itu ada beberapa metode yang ada dalam rekrutmen politik yaitu penarikan undian, rotasi, dan perebutan kekuasaan,

\section{Fungsi Rekruitmen Kader}

Pada Partai Gerindra metode rekruitmen politik yang digunakan adalah dengan Co-option yaitu anggota Partai
Gerindra yaitu kader yang memilih bakal calon internal dan eksternal sedangkan yang menetapkan bakal calon untuk diajukan dalam pencalonan adalah panitia penjaringan khusus tingkat daerah dan pengurus DPD Partai Gerindra DKI Jakarta.

Partai Gerindra adalah partai kader dengan singkatan Gerindra. Partai politik sudah sepatutnya kembali pada cita-cita awalnya sebagai saranan pendidikan politik. Kader adalah salah satu instrument bagi partai politik, kehadiran kader bisa untuk meningkatkan partai politik lebih maju. Dengan acara melakukan rekruitmen sebanyak-banyak kader, melakukan kegiatan partai politik, dan mengenalkan partai Gerindra kepada kalangan umum. Jadi ada dua model dalam rekruitmen politik yang dilakukan oleh lembaga politik, model terbuka secara umum lebih banyak dilakukan oleh beberapa partai di Indonesia termasuk Partai Gerindra. Proses rekruitmen politik adalah sarana penjaringan yang dilakukan oleh instansi politik kepada masyarakat umum untuk dijadikan kader-kader instansi politik tersebut. Umumnya rekruitmen politik yang dilakukan ini berbeda beda dalam proses perekruitannya ada yang terbuka dan ada yang tertutup dalam melakukan rekruitmen politk itu sendiri. ${ }^{2}$

Jenjang atau sistem karir dalam partai politik adalah suatu sistem penataan masa depan para aktivis partai menyangkut peran dan posisi mereka dari waktu ke waktu dalam berbagai posisi yang ada atau bisa dilalui lewat keterlibatan atau jasanya dalam partai politik. Posisi ini seperti pengurus partai di berbagai tingkatan atau jabatan publik. Sistem karir adalah jembatan menuju pelembagaan proseduralisme demokrasi yang secara praktis dibutuhkan bagi tercapainya integrasi internal dalam partai

\footnotetext{
2 Wawancara dengan Ketua DPD Partai Gerindra DKI Jakarta, Muhammad Taufik, tanggal 05 Maret 2019, pukul 11.00 sd Selesai, bertempat di Kantor DPRD DKI Jakarta.
} 
politik. Melalui sistem karir berbagai penataan relasi antar individu partai bisa dikelola. Sistem karir dapat didesain guna mengelola potensi konflik karena harapanharapan masa depan yang diandaikan oleh setiap individu partai (Sastroatmodjo, 1995).

\section{Partai politik diharapkan} menjalankan fungsi rekrutmen yang baik, yakni menempatkan kader-kader partai pada jabatan-jabatan di dalam partai dan jabatan-jabatan politik di luar partai (di lembaga eksekutif dan legislatif) berdasarkan kemampuan, kinerja, dan pengalaman kader yang bersangkutan (Rauf, 2000).

Fungsi rekrutmen kader dari calon anggota legislatif secara semi terbuka yang dilakukan oleh Partai Gerindra merupakan indikasi bahwa Partai Gerindra telah melakukan kaderisasi yang baik. Fungsi partai politik juga mencakup fungsi berkomunikasi dengan masyarakat dan kepentingan masyarakat untuk sosialisasi politik. Mengingat salah satu fungsi partai politik adalah melakukan kaderisasi untuk menghasilkan calon pemimpin. Dengan memilih dan menyeleksi dari kader internal maupun eksternal tentunya kader tersebut telah dipersiapkan secara matang untuk menjadi legislator dari tahun-tahun sebelumnya sehingga sudah melalui proses pembinaan.

\section{SIMPULAN}

Rekruitmen yang dianut oleh Partai Gerindra adalah pola partai terbuka semua masyarakat yang telah memenuhi persyaratan dan kriteria yang ditetapkan oleh Partai Gerindra dapat menjadi calon anggota legislatif dari Partai Gerindra DKI Jakarta bersifat terbuka dari kader internal maupun eksternal. Dalam proses rekrutmen calon legislatif Partai Gerindra DKI Jakarta sudah menggunakan mekanisme yang ditetapkan oleh pengurus partai yang dalam peraturan partai. Di dalam peraturan itu tercantum mengenai prinsip, sumber, mekanisme dan tahapan pencalegan, dan sebagainya. Adapun makna yang dapat dipetik dari proses rekrutmen itu adalah bahwa secara kelembagaan Partai Gerindra telah memiliki mekanisme yang relatif terbuka. Fungsi dari rekruitmen kader partai Gerindra harus menyeleksi dan mempersiapkan anggota-anggotanya yang dianggap mampu untuk calona nggota legislatif serta mampu memobilisasi partai sehingga memberi pengaruh besar dikalangan masyarakat untuk bersosialisasi dengan kebutuhan masyarakat. Fungsi rekrutmen kader dari calon anggota legislatif secara semi terbuka yang dilakukan oleh Partai Gerindra merupakan indikasi bahwa Partai Gerindra telah melakukan kaderisasi yang baik. Fungsi partai politik juga mencakup fungsi berkomunikasi dengan masyarakat dan kepentingan masyarakat untuk sosialisasi politik.

\section{UCAPAN TERIMA KASIH}

Terima kasih kepada Dosen Pembimbing Ari Ganjar Herdiansah dan Firman Manan di Universitas Padjadjaran dan JUPIIS untuk jurnal sehingga bisa terbit untuk jurnal ini, sekian terima kasih.

\section{DAFTAR PUSTAKA}

Al-Husainni, Y. D., \& Fuady, M. (2016). Strategi Komunikasi Politik Kader Muda Partai Gerindra. Yasser Dharma Al-Husaini , 2, No.1, 3.

Budiardjo, M. (2004). Dasar-Dasar Ilmu Politik. Jakarta.

Eko, S. (2003, Desember). Membuat Rekrutmen Legislatif Lebih Bermakna, Makalah pada Diskusi "Menyukseskan Penyelenggaraan Pemilihan Umum 2002 di Provinsi DIY". Puti Chaniago , 15.

Fajrina, A. H. (2017). Strategi Rekruitmen Partai gerindra dalam Kaderisasi Pemuda Di Kota Surabaya. Jurnal Politik Muda , 6, No.1, 5.

Haryanto. (1982). Sistem Politik: Suatu Pengantar. Yogyakarta: Liberty.

Kadir, A., (2013). Peranan Partai Politik dalam Menanggulangi Golongan Putih (Golput) pada Pemilihan Legislatif 2009, Jurnal Ilmu Pemerintahan dan Sosial Politik, 1 (1): 6575. 
Kleden, I. (2005). "Pemilu 2004 Seberapa Langsung Pemilihan Langsung?" dalam Syamsuddin Haris (Ed), Pemilu Langsung di Tengah Oligarki Partai: Proses Nominasi dan Seleksi Calon Legislatif Pemilu 2004. Jakarta: Gramedia.

Koentjoroningrat. (1998). Metode-Metode Penelitian Masyarakat. Jakarta: Gramedia.

Koirudin. (2004). Partai Politik dan Agenda Transisi Demokrasi: Menakar Kinerja Partai Politik Era Transisi di Indonesia. Yogyakarta: Pustaka Pelajar.

Nurdiansyah, F. (2018). Marketing Politik DPP Partai Gerindra pada Pemilu Legislatif 2014 JJurnal Ilmu Politik Politika, 9 Nomor 1, 6.

Pasaribu, P., (2017). Peranan Partai Politik dalam Melaksanakan Pendidikan Politik. JPPUMA: Jurnal Ilmu Pemerintahan dan Sosial Politik UMA, 5 (1): 51-59

Putra, F. (2003). Kebijakan Publik Analisis Terhadap Kongruensi Janji Politik Partai dengan Realisasi Produk Kebijakan Publik di Indonesia 1999-2003. Yogyakarta: Pustaka Pelajar.
Rauf, M. (2000). Konsensus dan Konflik Politik, Sebuah Penjajagan Teoritis. Jakarta: Dirjen Dikti Depdiknas.

Rifai, M. (2016). Marketing Politik Partai Gerindra Pada Pemilu Legislatif 2014 Di Kabupaten Karawang. Politikom Indonesiana , 1 No 1, 6.

Sastroatmodjo, S. (1995). Perilaku Politik. Semarang: IKIP Semarang Press.

Syamsir, \& Suryaney. (2005). Proses Penjaringan dan Penyaringan Calon Anggota Legislatif Perempuan di Kota Padang. Jurnal Ilmiah demokrasi , 5.

U.B, R. A., \& Sukmana, H. (2015). Model Rekruitmen Politik Calon Anggota Legislatif Oleh Partai Politik Di Kabupaten Sidoarjo. JKMP , 3, No.2, 12.

Wawancara dengan Ketua DPD Partai Gerindra DKI Jakarta, Muhammad Taufik, tanggal 05 Maret 2019, pukul 11.00 sd Selesai, bertempat di Kantor DPRD DKI Jakarta.

Wawancara dengan Sekretaris DPD Partai Gerindra DKI Jakarta, Husni Thamrin, tanggal 07 Maret 2019, pukul 14.00 sd Selesai, bertempat di Sarinah. 